\title{
The Need for Professional Growth of ELT Teachers in Ethiopia
}

\author{
Eba Mijena
}

College of Social Sciences and Education, Wollega University, Post Box No: 395, Nekemte, Ethiopia

\begin{tabular}{|c|c|}
\hline Abstract & Article Information \\
\hline \multirow{3}{*}{$\begin{array}{l}\text { This paper presents the need for professional growth of English language teachers in } \\
\text { Ethiopia. It indicates that English language teachers teach what they know, what they } \\
\text { have, what they think, and what they believe. They cannot give beyond what they have } \\
\text { and what they know. It argues that the poor competence and proficiency in English } \\
\text { language can be addressed by improving the quality of English language teachers. } \\
\text { Therefore, it emphasizes that the collaborative effort of teachers, schools/institutions } \\
\text { and teacher training institutions can make a difference in improving the quality of } \\
\text { English language teachers by designing different sustainable professional } \\
\text { development strategies which address the subject matter content, language skills, } \\
\text { language pedagogy and the curriculum that teachers currently teach. }\end{array}$} & $\begin{array}{l}\text { Article History: } \\
\text { Received : } 19-08-2013 \\
\text { Revised : } 25-09-2013 \\
\text { Accepted : 28-09-2013 }\end{array}$ \\
\hline & $\begin{array}{l}\text { Keywords: } \\
\text { professional growth } \\
\text { sustainable } \\
\text { ELT teachers }\end{array}$ \\
\hline & $\begin{array}{l}{ }^{*} \text { Corresponding Author: } \\
\text { Eba Mijena } \\
\text { E-mail: } \\
\text { eba.mijena@gmail.com }\end{array}$ \\
\hline
\end{tabular}

\section{INTRODUCTION}

English language education should bring about significant practical changes on student learning and its teaching should result in the proper development of language competencies. This demands that its teaching should be of world class standard. It is believed that the success of any type of education depends upon three key factors: the teacher, the curricula and the learner. Of these three, the relatively more important one is the teacher, who guides, controls, promotes or hinders learning. The importance of the teacher has not declined in spite of the fact that the emphasis on language education has shifted from teachercentered to learner-centered teaching/learning since the 1980s. The teacher still has the great role and responsibility of providing students with an environment in which students can learn efficiently and become independent learners who can reach the correct and sufficient knowledge; and subsequently evaluate, assimilate, adapt and reconstruct that knowledge according to their needs.

The facts indicated in the preceding paragraph imply that the English language teacher is instrumental to the quality of education in general and English language education and the quality of language learners in particular. This is because English is taught as a subject and used as medium of instruction Grade 9 onwards in Ethiopia. The competence and proficiency in English language is determined by the competence and proficiency of teachers in the English language. Nevertheless, in reality, this could not happen in the Ethiopian context where English is taught and learned as a foreign language. The output is disappointing! Students, who go to higher education institutions, completing their secondary level education, cannot even express themselves in all language skills. Why is this so? This might be attributed to different factors. But for me, English language teachers' professional growth is the most significant one which necessitates the change in the existing teacher knowledge, skill and attitude.

\section{ELT in Ethiopia}

The teaching of English began with the beginning of formal education in Ethiopia by 1908. Since then, it has experienced various curricular and methodological changes and developments. Teachers of the first three or four decades were entirely expatriates from India, the UK, and the USA until locally trained Ethiopians substituted them. 


\section{Eba Mijena}

Different writers (e.g. Alemu, 2004) indicate that with this shift, the teaching of English began to suffer from the lack of quality. There might of course be different contributing factors for the deterioration of language quality of which English language teacher's capacity plays a very critical role.

It is clear that English language learning in Ethiopia is entirely limited to the classrooms. There are few opportunities for students to practice the language outside the classroom context. Business centers, hospitals, courts, government institutions all use either the local or national language for day-today activities and office work. Hence, the teacher is found to be the sole source of knowledge and skill for the students. To put it in other words, Ethiopian students learn English in contexts where a) English is not a language of daily life, and b) English language teacher is the sole source of English, be it bad or good English. Students speak the English spoken by the teacher and write the same. In most cases, they use the same vocabulary as the teacher. Hence, Ethiopian students suffer from two major challenges. Firstly, the English language teachers who are very poor in the language and who use local languages dominantly in English language classrooms teach them, and secondly they do not have conducive environment to use the language in real contexts.

Ethiopian ELT teachers live in situations where they have to decide on different issues of English language instruction and instructional processes. They have double responsibilities in the classrooms. The first one is implementing the English curricula and the second one is filling the gap created because of the lack of practical exposures. These decisions however require them possess the necessary knowledge, skill and attitudes. Without having these important elements in the highest amount and quality, they will not be effective in helping the students learn. Thus, professional development agenda for English language teachers in Ethiopia is not only the issue of necessity but a mandatory one.

I had an opportunity to talk to English language teachers in schools during the English Language Teachers' Network held in March 2013 by Wollega University. My personal observations and informal interviews on how they think teaching in general and English language teaching in particular taught me a big lesson. This paper is the outcome of those meetings. The response I got was extremely surprising and reads like this "teaching English is giving students well organized grammar notes from different grammar books and explanations on the notes so as to help them broaden their knowledge". For most of these teachers, teaching English is
Sci. Technol. Arts Res. J., July-Sep 2013, 2(3): 160-168

imparting knowledge. This shows us that, in spite of curricular and methodological changes, most teachers still are mechanists and think mechanically.

English language teachers are still thinking and acting traditionally in the $21^{\text {st }}$ century where the active learning approach has taken over the traditional systems of teaching. In most teaching environments even today though the degree varies, the banking model of education is dominant. It is not only what teachers think about teaching but also the languages of instruction used at all levels, except in a few cases, have become the local languages than English in the English language teaching classrooms. Where English is used, even the English used is the 'Ethiopianized' or 'localized' English. By localized English I mean the English which has been assimilated to the local languages in accent, pronunciation, intonation and stress and found to be very different and very difficult in understanding in most cases. This English cannot serve them beyond the country's boundary. Hence, improvement in the professional competence of English language teachers becomes a critical issue in Ethiopia.

\section{The $21^{\text {st }}$ Century English Language Teacher}

The present globalized world requires graduates who can identify and solve problems and make significant contributions to the society. What should the $21^{\text {st }}$ century English language teachers be like then? What kinds of knowledge, skills and attitudes should they have? What kinds of professional ethics, professional values and professional responsibilities should they have? Today's teachers require the 21st century skills like critical thinking and problem solving, communication skills, collaboration and creativity and innovation skills. Moreover, today's globalized world requires teachers to be flexible and adaptable to changes as well.

It is very clear that knowledge is dynamic and the educational goals of this century are completely different from the goals of elitist education goals. The $21^{\text {st }}$ century English language teachers therefore have the responsibility of preparing English language learners, who would communicate in the language confidently, for the globalized world. They have the responsibility of preparing students who can understand the world, the dynamism of knowledge and change. The dynamism in the nature of knowledge requires one to cope up with the existing changes. Therefore, the $21^{\text {st }}$ century teachers should be highly competent, i.e. they have to be knowledgeable, skilled and attitudinally shaped in line with knowledge which the globalized world requires. It is therefore argued that this is the 


\section{Eba Mijena}

critical time when we have to rethink of who the English language teachers are in Ethiopia, what knowledge they have, what skills they have, and what attitude they have.

\section{The Need for Professional Growth}

As it is pointed out in the aforementioned section, the $21^{\text {st }}$ century teachers need critical skills to properly contribute in the globalized world. Therefore, the $21^{\text {st }}$ century professional development should (a) illustrate how a deeper understanding of subject matter can actually enhance problem-solving, critical thinking and other $21^{\text {st }}$ century skills and (b) enable the $21^{\text {st }}$ century professional learning communities for teachers that model the kinds of classroom learning that best promotes the $21^{\text {st }}$ century skills for students.

In line with the knowledge demand of this century, the Ethiopian government has introduced some reform actions in the teacher education systems of the country since 1994 . These reform actions were made to address the previous problems (inaccessibility, inequity, irrelevance, and poor quality) of the education system. The preservice teacher education has been redesigned with the very objective of developing trainees' skills, using appropriate methods for subject content and understanding the context of language teaching. There have also been attempts from the government to initiate some programmes like CPD (Continuous Professional Development), ELIP (English Language Improvement Programme) and Induction programmes in response to the findings of the study conducted by the Ministry of Education (2002) to improve the quality of teachers. But these programmes were generic and could not address the specific needs of English language teachers (Eba, 2011). Moreover, Eba (2011) indicated that the programmes in place were not need-based and they lacked sustainability. This necessitates the designing of professional development programmes specifically for English language teachers.

As it is indicated before, all the changes which are taking place and the prevailing problems in teacher education systems sought for quality teacher training. This is because, in today's dynamic developments in education as a whole and teacher education in particular, teachers are viewed as lynch-pin of all kinds of reform and are required to teach all students to world-class standards (Cochran-Smith, 2009). As Bolam (2000) argues, "the longer-term health of schools and students
Sci. Technol. Arts Res. J., July-Sep 2013, 2(3): 160-168

depends on well-educated teachers not just welltrained and well-informed ones" (Joyce and Showers, 2002). Thus, the demand on teachers to remain current in terms of their knowledge base is extremely vital (Richards and Farrell, 2005). Similarly, Guskey (2000) indicates that teachers should keep abreast with the rapidly changing knowledge basis in education, and that they need to transform their roles in modern educational reforms. Therefore, such inevitable changes necessitate teacher development. Bone (1987) cited in Hoyle and John (1998) states that unless teachers are prepared to meet the needs of a new situation, they cannot be effective in the climate of educational reform.

What is the development I am talking about? It is professional development! What is it? Why is it important? As Bolam (1993) states, "any... activities engaged in by teachers which enhance their knowledge and skills and enable them to consider their attitudes and approaches to the education of children, with a view to improve the quality of the teaching and learning process" is professional development. From this definition, we can see that professional development refers to 1) any activities engaged in by teachers, 2) activities which are planned to enhance teachers' knowledge, skill, attitude and practices, and 3 ) activities whose goal is the improvement of the education of children. The professional development of English language teachers is a critical issue in Ethiopia. This is because an earthshaking and highly qualified curricula or methodology cannot be realized without the efficiency of the teachers in the area. For example, Hargreaves (1989) notes that "change in the curriculum is not effected without some concomitant change in the teacher." This is because it is the teacher who is responsible for delivering the curriculum at the classroom level. This is why professional development is currently given unprecedented emphasis in the education of teachers. Professional growth is needed for influence! It is needed to make a difference! And therefore the Ethiopian English language teachers have to grow!

\section{The Power of Professional Growth}

Growth here is referred to the progress in the professional knowledge, skill and attitude through the engagement of teachers in professional development activities. It is fundamental aspect of a life process. There is a good lesson learned from the life of an eagle on how renewing self affects life. 


\section{The Eagle}

It is believed that an eagle has the longest life-span of its species. It can live up to 70 years. To reach this age however, it must go through a process of renewal when it is 30 years old. In its $40 \mathrm{~s}$, the eagle's long and flexible talons can no longer grab prey which serves as food. Its long and sharp beak becomes bent. Its old-aged and heavy wings, due to their thick feathers, become stuck to its chest and make it difficult to fly. Then, the eagle is left with only two options of either to die or go through a painful process of change which lasts 150 days. How does an eagle do this? What is the significance of this to an eagle? The process requires that the eagle has to find a hidden place high in the mountains to knock its beak against a rock until it plucks it out. After plucking it out, the eagle will wait for a new beak to grow back and then it will pluck out its talons. When its new talons grow back, the eagle starts plucking its old-aged feathers. And after five months, it takes its famous flight of rebirth and lives for $\mathbf{4 0}$ more years.

The following lessons can be drawn from the story:

1. Teachers need to get free from old beliefs, old ways of thinking and old ways of acting by engaging in change processes, i.e. professional development.

2. Self renewal is at the heart of real change. This tells us that teachers should take hard decisions to renew themselves using different opportunities (reading, researching, teamwork, peer learning, peer evaluation, etc). They should see themselves as professionals and take an active role in their own learning.

3. Change is a process, not an event. It requires continuous engagement in various professional development activities. It takes 150 days (5 months) for an eagle to change and enjoy the rest of its life.

4. Commitment for change is another important point which can be learned. No matter how change demands lots of challenges the eagle has made it!

\section{Aspects of Teacher Change}

English language teachers in the globalized world need to grow in different aspects: knowledge, attitude and skill. This is because unless the teaching staff change, it is impossible to bring about real change in student learning.

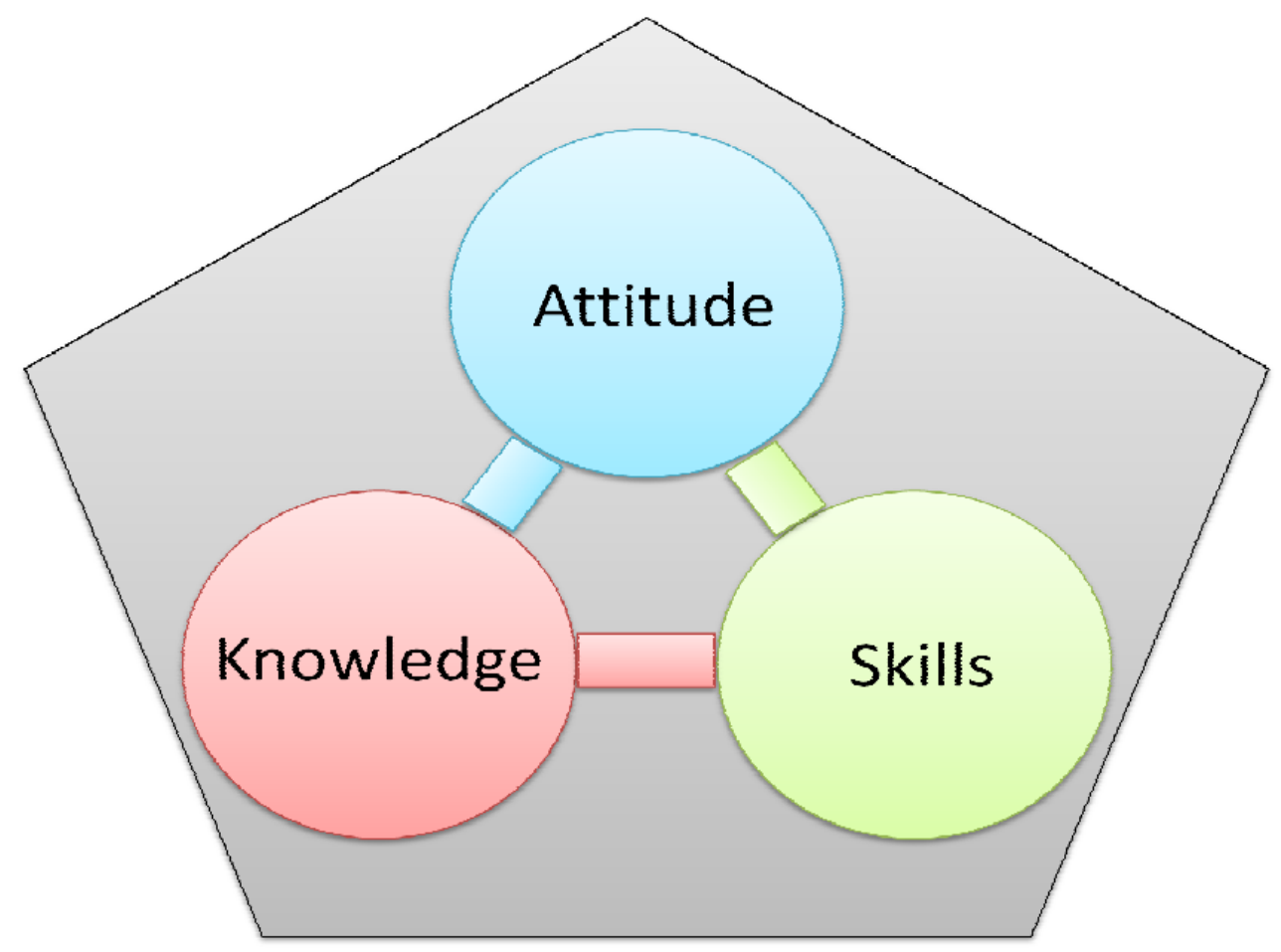

Figure 1: Major components of professional growth 


\section{Eba Mijena}

Attitude: beliefs, attitudes and perceptions are used interchangeably in this paper. Attitude is the area where teachers need change with the changing globalized world. Attitude of course cannot change overnight and needs long time. This means it changes through the course of time. As Borg (2001) indicates 'belief' as a general term is "... a proposition which may be consciously or unconsciously held, is evaluative in that it is accepted as true by the individual, and is therefore imbued with emotive commitment; further, it serves as a guide to thought and behavior." Further definition has been given by Woods (1996) who argues that a teacher belief is "..... the entity of what teachers embrace, including attitudes, values, beliefs, thinking, images, knowledge, conception, working principles, practical knowledge, and implicit theories". The definitions given here seem comprehensive. But one can ask how is it possible to know the kinds of beliefs which individuals have? As it can be seen from the definition given by Borg, beliefs are reflected in practice. How they are reflected in practice can indicate whether they are positive or negative beliefs. When we talk about English language teachers' beliefs, we are also talking about the views they hold about students, language learning, language teaching, language and the like. It is believed that teachers' beliefs had a much greater influence than teachers' knowledge on their lesson planning, decision-making, and general classroom practice. The most important question in discussing about beliefs is that, where do these attitudes root? Why do they take a long time? Different reasons can be mentioned. Attitudes, in the first place, are views individuals hold towards something or someone. These attitudes are the results of the lived and the received experiences. By the lived experiences, I mean the experiences which one practically has lived, tested through life and experimented with. The received experiences however refer to the experiences one gets or learns from a family, a friend, a neighbor, and the like. These second type generally refers to the experiences obtained from what individuals can see and hear.

Skills: a skill refers to the practical or technical knowledge which one should have to perform or do an activity or something. Skill is obtained only from practical experience- skill is not inborn; it is not given by birth. It cannot be acquired by telling. A teacher of English who knows (knowledge) about writing or speaking very well might not perfectly use (skill) them in the real world. In other terms, this means that one can have the knowledge of something but not necessarily the skill of performing it. We can also relate it with an engineer who might know how houses can be constructed but does not have the technical skill of doing it. We can also take
Sci. Technol. Arts Res. J., July-Sep 2013, 2(3): 160-168

further examples like swimming which cannot be learned at all by telling rather by making an individual engage in the actual activity. These analogies teach us that competences in the reading, writing, listening, speaking and vocabulary and other related language items are fundamental for language teachers through professional development activities. The English language teachers need to have high level of competence in the language skills. They need to be model for their students.

Knowledge: knowledge refers to the conceptual understanding an individual has about something. What should English language teachers know? This will take us to considering the work of Shulman (1986 and 1987). Shulman (1987) identifies seven categories to provide a framework for teacher knowledge base which include: content knowledge, general pedagogical knowledge (e.g. classroom control, using group work), pedagogical content knowledge, curriculum knowledge, knowledge of learners and their characteristics, knowledge of educational contexts (e.g. schools and the wider community), and knowledge of educational ends purposes and values. This implies that teachers need to have the knowledge of various issues in the teaching and learning contexts- the content, pedagogy, the learners, the language teaching materials and the foreign language teaching context. It might be of very important to look at some of them.

1. Content knowledge is used interchangeably with subject matter knowledge and refers to the knowledge which teachers need to have to significantly influence student learning. It refers to what teachers need to know about what they teach, and constitutes knowledge that would not be shared by teachers of other subject areas. Content knowledge helps teachers plan and deliver their lessons properly; the knowledge helps them make proper decisions in teaching and learning.

In line with the significance of content or subject matter knowledge, Shulman (1987) suggests that content knowledge is a significant aspect of teaching since it affects planning, task setting, questioning, explaining, giving feedback and assessment. Moreover, (citing Anderson, 1989, Ball 1990, Borko and Putnam, 1996, McDiarmid, Ball, and Anderson, 1989), Borko (2004) states that

To foster students' conceptual understanding, teachers must have rich and flexible knowledge of the subjects they teach. They must understand the central facts and concepts of the discipline, how these ideas are connected, and the processes used to establish new knowledge and determine the validity of claims. 


\section{Eba Mijena}

Professional development programmes, which focus on subject matter, significantly help teachers develop powerful understanding. It is believed that content knowledge is significant for teaching, evaluation of textbooks, and preparation of teaching aids. This is because content knowledge is the basis for undertaking these activities effectively. It plays a valuable role in the quality of the lesson to deliver to students. It is therefore believed that teachers who have sufficient subject matter knowledge teach comfortably and confidently than those who have less.

It is clear that teacher knowledge changes through intensive professional development programmes. Therefore, English language teachers need to continually add to their subject knowledge to keep up-to-date with changes in a subject area.

2. Pedagogical content knowledge is the knowledge which refers to the knowledge of how to teach a specific subject, for example how to teach English. It combines the knowledge of content and the methodology of a particular subject area. This knowledge is fundamental for language teachers. It could include course work in areas such as curriculum planning, assessment, reflective teaching, classroom management, teaching children, teaching the four skills, and so on. A sound grounding in relevant pedagogical content knowledge should prepare teachers to be able to do things such as the following: understand learners' needs, diagnose learners' learning problems, plan suitable instructional goals for lessons, select and design learning tasks, evaluate students' learning, design and adapt tests, evaluate and choose published materials, adapt commercial materials, make use of authentic materials.

3. General pedagogical knowledge refers to the general knowledge and beliefs hold about teaching, learning, and learners. It includes the knowledge of various strategies for creating learning environments and conducting lessons; strategies and arrangements for effective classroom management; and more fundamental knowledge and beliefs about learners, how they learn, and how learners can be fostered by learning.'

4. Pedagogic knowledge is also a knowledge required by English language teachers. This refers to the general skill of pedagogy.

5. Curriculum knowledge is knowledge of what should be taught to a particular group of pupils. It requires understanding of children's learning potential, national syllabuses, assessment, school planning documents and year group plans.
Sci. Technol. Arts Res. J., July-Sep 2013, 2(3): 160-168

6. Contextual knowledge is another important aspect of teacher knowledge. A key factor in understanding any teaching situation is the social and physical context - the rules, facilities, values, expectations, and personal backgrounds, which act as resources, constraints, and direct influences on teaching and learning (Posner 1985). Socio-cultural perspectives on learning emphasize that learning is situated; that is, it takes place in specific settings or contexts that shape how learning takes place. Language teachers teach in many different contexts, and in order to function in those contexts they need to acquire the appropriate contextual knowledge that will enable, for example, a primary school teacher needs to learn how to be an effective EFL teacher of young learners or children. Different contexts for teaching create different potentials for learning that the teacher must come to understand.

Depending on the context, the learners may represent different age, social, economic, cultural, and educational backgrounds. Different teaching contexts hence present different notions of the process of language teaching (Zeichner and Grant, 1981).

The following issues need to be considered in contextual understanding:

$\checkmark$ Who are the learners?

$\checkmark$ What are the appropriate materials for these groups of learners?

$\checkmark$ What are the proper topics?

$\checkmark$ How should the materials be presented to the group?

$\checkmark$ What are the resources available?

$\checkmark$ What does the classroom condition look like?

\section{Roles and Responsibilities of Stakeholders}

It has been indicated that the professional growth of English language teachers in Ethiopia is not only the issue of necessity but it becomes a mandatory one. It is therefore not something which has to be left to the government alone. It requires the involvement and the collaborative effort of English language teachers themselves, their employers/ schools or institutions and teacher education institutions to bring about the needed change. Hence, the roles of these stakeholders have been discussed in the following subsections.

\section{a. The role of Teachers'}

This is the role which refers to the readiness, willingness and commitment an individual English language teacher has for learning and growth. Real change for development usually comes from inside. A language teacher who is not psychologically ready to learn and who does not have willingness 


\section{Eba Mijena}

for change cannot at all grow. Even if he/she physically seems convinced, he/she will not be productive until the psychological readiness comes into play. In line with this, Roberts (1998) stresses the importance of self-awareness for professional development. It is not only what is initiated by the government but also teachers are expected to have their own personal professional development plans. English language teachers should be conscious of their strengths and weaknesses, of the nature of their own development and knowledge, and of their own beliefs about teaching and learning. Besides having professional development plan, it would be very important for teachers to identify any sort of professional development and engage in. Teachers are those who enjoy the benefits of change as a result of their engagement in professional development activities. How do teachers do this? The following worth mentioning:

$\checkmark$ Teachers need to have their own professional development plans. This means that teachers themselves know what kind of knowledge they have and what they lack, their attitudes, and the skills they lack. These plans could include: watching movies to improve their comprehension skills, reading books and news papers for the improvement of their vocabulary or word power.

Even if there are opportunities to learn, time for learning, some teachers might not positively react to it. The wise learn; the fool won't!

\section{b. The role of Institutions/Schools}

School is an influential place where knowledge and experiences are acquired. It is a place of influence, a place of sharing experiences and acquiring experiences. Schools or institutions should not just be considered as places where students are gathered, attend classes and go; teachers wear in white, go to classes, lecture for 40 minutes or so and go. There are many, be students or teachers, who think schools or institutions are just these and created to give such and only such functions. These kinds of thinking are harmful and affect every action of the teacher and the student. There are lots of schools, teachers and students which aim only at the finishing of chapters of books without students learning something. If you ask teachers to what extent they have taught, their responses go like this "These numbers of chapters have been done and this much is left". Finishing chapters are the targets than what is learned by the students. The $21^{\text {st }}$ century schools or institutions should get-rid of such kinds of old thinking and focus on how much the students learn.

Schools are places where pupils and teachers experiment, investigate solve-problems, theorize,
Sci. Technol. Arts Res. J., July-Sep 2013, 2(3): 160-168

seek solutions and engage in the development of one's country. Hence, what are the important roles which should be played by schools in the professional growth of English language teachers? There might be several roles but I can put them in one sentence: schools or institutions should create community of learners. This means that schools can create and facilitate environments so that teachers learn and grow. Schools which don't create such conditions are not schools but just simple buildings as they are not deliberating the function of schools. Most of our schools lack these initiatives. They employ teachers but no plan for the improvement of the teacher's knowledge, attitude and skill. Most of them wait initiatives by the government but schools should design different strategies for the growth of their employees.

What does the experience from other countries tell us? For example, the Australian experiences tell us how schools or institutions give attention to teacher development issues. The development of teachers is their priority agenda. the professional development of teachers is highly valued in Australian schools. Schools begin by professional development programmes rather than by teaching itself. In line with this point, Grundy and Robison (2004) state that "In many schools in Australia the school year begins with one or more 'pupil free' days devoted to planning and professional development". In the country, novice teachers will not start teaching unless they participate in professional development. Such practices, providing professional development training in general and incorporating it in the school calendar as a primary activity before starting teaching itself, signal the place of professional development in Australian schools. This might be because they are well aware of the secrets in improving teacher knowledge, i.e. improving quality of education. Creating context for teacher learning will become the most important role of schools or institutions.

\section{c. The Role of Teacher Training Institutions}

Teaching is the profession on which all other professions depend. Indeed, everybody who is anybody was enabled to become somebody by a teacher. Therefore, teacher education or training institutions play critical roles in the preparation of teachers. Among others, the most important role is that they uncover the conceptions, beliefs, and values that underlie the thoughts that guide teachers' classrooms practices. Moreover, they equip the would-be English language teachers with the necessary content and pedagogical knowledge. English language teachers' beliefs about best teaching were guided by their previous experience as language learners as well. It is agreed that the long years of experiences they had as students in 


\section{Eba Mijena}

schools affect the whole thinking they have about English language teaching and learning. Therefore, teacher education institutions in Ethiopia should play their vital roles in preparing and shaping teachers of English for the $21^{\text {st }}$ century. They need to rethink of their programmes so as to fill-in the existing gaps in the teachers' knowledge, skills and attitudes.

\section{Features of Effective Professional Development}

The first feature which makes a professional development effective is sustainability. Effective professional development programmes are not oneoff shot programmes. They have to be sustainable. It is of course not only the issue of sustainability which makes a professional development programme effective but also the programme should have proper follow up and feedback mechanisms. In line with this, Underhill (1997) indicates that professional development involves teachers in a constant process of learning about their practice and discovering and using their own potential. At the same time, these activities should take into account the adult learning theory. As a group, adult learners are self-directed, ready to learn, experienced, taskcentered, and intrinsically motivated (Knowles, 1990). Thirdly, engaging teachers in reflective practice- this could be reflection in practice and reflection on practice (Schon, 1987 and 1991).

Effective professional development engages teachers in learning opportunities that are supportive, job-embedded, instructionally-focused, collaborative, and ongoing. Effective professional development for teachers is instructionally-focused because it emphasizes subject area content and pedagogy as well as student learning outcomes.

\section{Professional development strategies}

I would like to suggest some strategies for professional growth of English language teachers in the context of Ethiopia. These might include:

a. Engagement in English language seminars/ conferences/workshops/symposia

b. English language seminar days/research daysteachers should have some hours devoted for sharing research and teaching experiences in a week.

c. Peer observation- two English language teachers observe each others' classes for feedback and comments on how each of them does teaching.

d. Peer teaching/team teaching- two or more English language teachers plan (prepare annual as well as lesson plans) and take classes (initiate discussions in classes and facilitate learning) together. They also engage in evaluating students together.
Sci. Technol. Arts Res. J., July-Sep 2013, 2(3): 160-168

e. Journal writing- the teaching journal prepared by a teacher includes all observations and reflections written by a teacher on the delivery of a lesson.

f. Teacher support group- teachers of common interest can come together, for example, reading groups. This is where teachers who want to read and share experiences can make a group and learn from one another.

g. Action research- teachers either individually or in group identify a problem, make analysis and take actions in solving the problem.

h. Reading days- English language teachers or schools can agree and devote some hours of a week for reading in their schools. Books which have significance for the development of either subject matter knowledge or skill can be identified by an institution or one teacher (teacher leader) who can take the initiative.

i. Self-evaluation: English language teachers' selfevaluation of their own practices can be considered as a commitment to analysing and evaluating their own teaching acts. It involves reflecting, questioning or engaging in critical reflective inquiry over one's own practice (Wallace 1991). Furthermore, self-evaluation is considered as fundamental for the professional development of teachers towards autonomy.

\section{CONCLUSION}

Ethiopia aspires to be a middle income country by 2020 . This aspiration can become true if and only if capable human capital is available, especially in the area of education. It is because education is the basis for all development aspects. It is therefore here that where the issue of teachers' professional and pedagogical knowledge and skills becomes a priority area. It is believed that "No person is more influential in the day-to-day life of students than the teacher in the classroom" (California Education Policy Seminar (1998) cited in Levin (2003). This shows that capacity development of Ethiopian EFL teachers is necessary to prepare them to meet the needs of the $21^{\text {st }}$ century schools. The preparation of Ethiopian EFL teachers for the global economy has to be the concern of all stakeholders. The poor competence and proficiency in English language skills has to be a priority concern, which leads to the designing of need based and sustainable professional development programmes which are particularly meant for English language teachers in the area of improving content knowledge, the language teaching pedagogy, language skills and the curriculum teachers currently teach in schools. 


\section{Eba Mijena}

\section{REFERENCES}

Alemu, H. (2004). An Evaluative Study of ELT Practices in Secondary Schools in Ethiopia: Unpublished PhD Thesis, Central Institute of English and Foreign Languages, Hyderabad.

Bolam, R. (1993). Recent Developments and Emerging Issues. In GTC Trust (ed.), The Continuing Professional Development of Teachers. London: GTC Trust.

Bolam, R. (2000). Emerging Policy Trends: Some Implications for Continuing Professional Development. Journal of In-Service Education 26(2): 267-280.

Borg, M. (2001). Key Concepts in ELT: Teacher's Beliefs. ELT Journal 55:186-188.

Borko, H. (Nov., 2004). Professional Development and Teacher Learning: Mapping the Terrain. Educational Researcher 33( 8): 3-15.

Cochran-Smith, M. (2009). The New Teacher Education in the United States: Directions Forward. In: Furlong, J., Cochran-Smith, M. and Bernnan, M (eds), Policy and Politics in Teacher Education (9-20). London and New York: Routledge.

Eba Mijena (2011). A Study of Professional Development Practices and Challenges in the Context of Primary English Education Reforms in Ethiopia. Unpublished $\mathrm{PhD}$ Thesis. The English and Foreign Languages University, Hyderabad, India.

Grundy, S. and Robison, J. (2004). Teacher Professional Development: Themes and Trends in the Recent Australian Experience, in Day and Sachs (eds.), International Handbook on the Continuing Professional Development of Teachers (146-164). England: Open University Press.

Guskey, T.R. (2000). Evaluating Professional Development. California: Corwin Press.

Hargreaves, A. (1989). Curriculum and Assessment Reform. Toronto: OISE Press.

Hoyle, E. and P. John (1998). Teacher Education: The Prime Suspect. Oxford Review of Education 24(1): 6982.
Sci. Technol. Arts Res. J., July-Sep 2013, 2(3): 160-168

Joyce, B. and Showers, B. (2002). Student Achievement Through Staff Development. Alexandria, VA: ASCD.

Knowles, M. (1990). The Adult Learner: A Neglected Species ( $4^{\text {th }}$ ed.). Houston, TX: Gulf.

Levin, B. (2003). Case Studies of Teacher Development: An In-Depth Look at How Thinking About Pedagogy Develops Over Time. London: Lawrence Erlbaum Associates Publishers.

Ministry of Education. (2002). Quality and Effectiveness of Teacher Education in Ethiopia, Addis Ababa.

Posner, G. (1985). Field experience: A guide to reflective practice. New York: Longman.

Richards, J. C., and Farrell, T. S., (2005). Professional Development for Language Teachers: Strategies for Teacher Learning. Cambridge: Cambridge University Press.

Roberts, J. (1998). Language Teacher Education. London: Arnold.

Schön, D.A. (1987). Educating the Reflective Practitioner: Towards a New Design for Teaching and Learning in the Profession. San Francisco: Jossey-Bass.

Schön, D.A. (1991). The Reflective Practitioner: How Professionals Think in Action. London: ASHGATE.

Shulman, L. (1986). Those Who Understand: Knowledge Growth in Teaching. Educational Researcher 15(2): 414.

Shulman, L. (1987). Knowledge and Teaching: Foundations of the New Reform. Harvard Educational Review 57(1): 1-22.

Underhill, A. (series ed.) (1997). The teacher development series. In: Head, $\mathrm{K}$ and Taylor, P. Readings in Teacher Development. Oxford : Heinemman. VII.

Wallace, M. J. (1991). Training Foreign Language Teachers: A reflective approach. Cambridge: Cambridge University Press.

Woods, D. (1996). Teacher cognition in language teaching. Cambridge: Cambridge University Press.

Zeichner, K., and C. Grant. (1981). Biography and social structure in the socialization of student teachers. Journal of Education for Teaching 1: 298-314. 